Lecturer in Chemistry at Canterbury University College, Christchurch, N.Z., for his guidance and assistance with the method and apparatus for determining fluorine; and to Mr L. M. Wright, Tea Controller, for supplying samples of the teas.

\title{
REFERENCES
}

Chamberlain, G. (1944). N.Z. F. Sci. Tech. 26, sect. B, p. 90.

Chamberlain, G. (1946). N.Z. F. Sci. Tech. 28, sect. B, p. 154.

Cheng, L. T. \& Chou, T. P. (1940). Chin. F. Physiol. 15, 263.

Clifford, P. A. (1945). Э. Ass. off. agric. Chem., Wash., 28, 277.

Crutchfield, W. E. Jr. (1942). Industr. Engng Chem. (Anal. ed.), I4, 57.

Dahle, D., Bonnar, R. U. \& Wichmann, H. J. (1938). F. Ass. off. agric. Chem., Wash., 2 r, 459.

Dean, H. T. (1943). F. Amer. Wat. Whs Ass. 35, 116 r.

Denmead, C. F. (1946). N.Z. Y. Sci. Tech. 28, sect. B, p. 158.

Harrison, M. F. (1949a). N.Z. dent. F. 45, 2.

Harrison, M. F. (1949b). Brit. J. Nutrit. 3, 166.

Lockwood, H. C. (1937). Analyst, 62, 775.

McCance, R. A. \& Widdowson, E. M. (1946). Spec. Rep. Ser. med. Res. Coun., Lond., no. 235, 2nd ed. Ockerse, T. (1941). S. Afr. med. F. 15, $26 \mathrm{I}$.

Reid, E. (1936). Chin. J. Physiol. 10, 259.

Smith, H. V., Smith, M. C. \& Vavich, M. (r942). Quoted by Smith, H. V. (1942). Publ. Amer. Ass. Advance Sci. 19, 12.

Van der Merwe, P. K. (1940). Onderstepoort $\mathcal{~ F . ~ v e t . ~ S c i . ~} 14,359$.

Weaver, R. (1944). Brit. dent. F. 76, 29.

\section{Urinary Excretion of Fluorine in some New Zealand Subjects}

\author{
BY MARION F. HARRISON \\ Department of Nutrition Research, Otago Medical School, Dunedin, \\ New Zealand
}

(Received 26 October 1948)

During recent years much attention has been directed towards the possible relation between a low fluorine intake, and a high incidence of dental caries. In the United States of America drinking water appears to be the main dietary source of fluorine, and the optimal amount of fluorine for prevention of dental caries without producing fluorosis has been suggested as $\mathrm{I} \cdot 0$ p.p.m. (Dean, 1943). On the other hand, fluorosis has occurred where the water supply had I p.p.m. or less, in England (Bromehead, Murray \& Wilson, 1943), and in Morocco (Murray \& Wilson, I948). This is possibly caused by an inadequate diet or by the inclusion in the diet of some other major contributor of fluorine as, for example, fish or tea (Reid, 1936; Klement, 1938; Harvey, 1945; Clifford, 1945).

However, in New Zealand, of the potable waters so far examined, only one, supplying but a small number of inhabitants, has a fluorine content of more than 0.5 p.p.m., most of the contents being in the range $0.05-0.3$ p.p.m. (Chamberlain, 1944, 1946; Denmead, 1946).

Machle, Scott \& Largent (1942) showed that a normal experimental subject on an unselected diet maintained an equilibrium between fluorine intake and output at 
a level of about $0.5 \mathrm{mg}$./day; over $80 \%$ of the ingested fluorine being excreted in the urine. If the daily intake of fluorine was increased by $6 \mathrm{mg}$., storage of fluorine occurred, even though there was an increase in its excretion. McClure \& Kinser (1944) reported, from an extensive study, that the fluorine content of the urine was directly proportional to the fluorine content of the drinking water through the range $0.5-5.1$ p.p.m. When the drinking water contained less than 0.5 p.p.m. the urinary content was $0.3-0.5$ p.p.m.

In view of the meagre contribution made by the water supplies contrasted with the relatively high fluorine content of tea infusions, as shown in the previous paper (Harrison, 1949b), coupled with the universal popularity of tea as a beverage in New Zealand, it appeared desirable to find the range of fluorine excretion in the urine, and to find out the extent to which it was influenced by tea consumption.

\section{EXPERIMENTAL}

Plan of study. In the first experiment, 24-hr. collections of urine were obtained from fifty-one medical students comprising seventeen women and thirty-four men. All were in good health and were consuming water from the Dunedin municipal supply, containing 0.05 p.p.m. fluorine (Denmead, 1946). Since these preliminary results indicated a positive correlation between tea consumption and urinary excretion of fluorine (see below), a second experiment was undertaken to compare fluorine excretion when tea was omitted with that during normal tea consumption. The twenty-eight volunteers were required to go without tea for 8 days, and to substitute for it hot water containing a little milk. They were requested not to consume any shellfish, or alcoholic beverages and to record details of the diet from the 6th to 8th day. A 24-hr. collection of urine was made on the 8th day.

For the next 8 days the subjects were allowed their customary amount of tea, but were still required to abstain from the foods and beverages specifically mentioned above, and to keep dietary details as before. A further 24-hr. collection of urine was made at the end of this period.

McClure, Mitchell, Hamilton \& Kinser (1945) considered that 3 days were sufficient for the body to reach equilibrium when the fluorine intake was altered. However, since only I day's collection was asked of the subjects in the second series, a preparatory period of 7 days was imposed to ensure a steady state of fluorine excretion.

Collection of urine. Wide-mouthed $2 \mathrm{l}$. bottles, fitted with ground glass stoppers, and containing two drops of toluene, were used for direct collection of the urine. As each specimen was received for analysis the volume and specific gravity were recorded, and the chloride content estimated by the method of Whitehorn (I92I). From this was calculated the weight of silver sulphate required to precipitate the chloride and iodide in $100 \mathrm{ml}$. urine.

Estimation of fluorine. The method employed for steam distillation and titration was that of Dahle, Bonnar \& Wichmann (1938), with some further modifications introduced by the author (Harrison, 1949a). For ashing the sample, the method was that of McClure \& Kinser (1944). To precipitate the chloride in the distilling flask, 
solid silver sulphate was used in place of the silver perchlorate solution advocated by McClure \& Kinser (1944), since the former was more readily available, and the presence of sulphate did not affect the distillation. An excess of $0.05 \mathrm{mg}$. above the calculated amount of silver sulphate was used, to ensure complete precipitation.

Table 1. Excretion of fluorine in the urine by fifty-one students drinking tea (Exp. 1), and by twenty-eight subjects when drinking, or abstaining from, tea (Exp. 2)

(The standard deviations for Exps. I and 2 are given beneath the means in parentheses.)

\begin{tabular}{|c|c|c|c|c|c|c|c|c|c|}
\hline \multirow[b]{3}{*}{ Exp. no. } & & & & \multirow{3}{*}{$\begin{array}{l}\text { Milk and } \\
\text { hot water } \\
\text { consumed } \\
\text { (ml./day) }\end{array}$} & \multirow{3}{*}{$\begin{array}{c}\text { Tea infusion } \\
\text { consumed } \\
\text { (ml./day) }\end{array}$} & \multicolumn{4}{|c|}{ Analysis of 24-hr. urine } \\
\hline & \multicolumn{3}{|c|}{ No. of subjects } & & & \multirow{2}{*}{$\begin{array}{l}\text { Volume } \\
\text { (ml.) }\end{array}$} & \multirow{2}{*}{$\begin{array}{l}\text { Specific } \\
\text { gravity }\end{array}$} & \multicolumn{2}{|c|}{ Fluorine } \\
\hline & Males & Females & Total & & & & & (mg./day) & (p.p.m.) \\
\hline$I$ & 34 & 17 & 51 & - & $\begin{array}{c}588 \\
(349)\end{array}$ & $\begin{array}{l}1507 \\
(427)\end{array}$ & 1.018 & $\begin{array}{c}0.49 \\
(0.19)\end{array}$ & $\begin{array}{c}0.33 \\
(0.13)\end{array}$ \\
\hline 2 & 5 & 23 & 28 & $\begin{array}{c}77^{\circ} \\
(341) \\
-\end{array}$ & $\begin{array}{c}915 \\
(349)\end{array}$ & $\begin{array}{l}1539 \\
(554) \\
1579 \\
(529)\end{array}$ & $\begin{array}{l}1.017 \\
1.015\end{array}$ & $\begin{array}{l}0.27 \\
(0.11) \\
0.52 \\
(0.21)\end{array}$ & $\begin{array}{l}0.18 \\
(0.069) \\
0.33 \\
(0.12)\end{array}$ \\
\hline$I$ and $2^{\circ}$ & $\begin{array}{l}\overline{39} \\
39\end{array}$ & $\frac{40}{40}$ & $\begin{array}{l}40 \\
39 \\
79\end{array}$ & - & $\begin{array}{l}804 \\
599 \\
705\end{array}$ & $\begin{array}{l}1547 \\
1518 \\
1532\end{array}$ & $\begin{array}{l}1.015 \\
1.019 \\
1.017\end{array}$ & $\begin{array}{l}0.50 \\
0.51 \\
0.50\end{array}$ & $\begin{array}{l}0.33 \\
0.33 \\
0.33\end{array}$ \\
\hline
\end{tabular}

- Excretion of fluorine by seventy-nine subjects-forty females and thirty-nine males-calculated from the combined results of Exps. I and 2.

The blank. Blank estimations on the reagents and apparatus were carried out regularly, and the fluorine found amounted on the average to $0.3 \mu \mathrm{g} . / 40 \mathrm{ml}$. distillate. This agrees with the values reported by Van der Merwe (1940) of $0.3-0.5 \mu \mathrm{g} . / 40 \mathrm{ml}$. distillate, by Clifford (1944) of $2-3 \mu \mathrm{g} . / 150 \mathrm{ml}$. distillate, and by the Sub-committee of the Analytical Methods Committee (1944), of $1 \cdot 5 \mu \mathrm{g} . / \mathrm{r} 50 \mathrm{ml}$. distillate. It is therefore assumed that the factors causing the blank elsewhere were also operating in these estimations. The value of $0.30 \mu \mathrm{g} . / 40 \mathrm{ml}$. was subtracted from each estimation of fluorine.

Duplicate analyses of five samples of urine all agreed within $2 \%$; in view of this only single analyses were carried out on each specimen.

RESULTS

The values obtained are recorded in Table I.

\section{DISCUSSION}

First experiment. The mean values for urinary excretion of fluorine, namely $0.49 \mathrm{mg}$./day, or 0.33 P.p.m., were in agreement with the findings of McClure \& Kinser (1944), for subjects consuming water containing less than 0.5 p.p.m. Statistical analysis of the results showed correlation between the volume of tea consumed and total fluorine excreted $(r=0.566, t=4.23)$. The mean excretion of chloride in the urine was $6.95 \mathrm{~g}$. in terms of chlorine/day (S.D. $=2 \cdot 14$ ) or $4.88 \mathrm{~g} . / 1 . \quad($ S.D. $=\mathrm{I} \cdot 66$ ). Although Machle et al. (1942) found a correlation between fluorine and chlorine excretion, no correlation was found in this study $(r=-0.55, t=0.34)$.

Second experiment. The results in the period with tea agree closely with the findings 
in the first experiment. Comparison of results from the 'with tea' and 'without tea' periods shows that the difference in total excretion of fluorine is significant $(t=5.57$, $P<0.01)$, as is also the difference in concentration of fluorine in the urine $(t=5.77$, $P<0.01)$. Again there was a significant correlation between quantity of tea consumed and daily fluorine excretion $(r=0.62, t=4.03)$. From these results it appears that tea is a major source of fluorine in New Zealand diets.

Table $\mathrm{r}$ shows that the excretion of fluorine was the same for both sexes, although it must be borne in mind that no results were obtained for pregnant and lactating females, who may possibly show higher retention of fluorine. Further, the mean excretion for seventy-nine subjects taking tea, $0.5 \mathrm{mg}$./day, or 0.33 p.p.m., is in line with the results of McClure \& Kinser (1944), in that, when domestic water contains less than 0.5 P.p.m., the urine contains $0.3-0.5$ p.p.m.

Calculation from the mean consumption of tea, $915 \mathrm{ml}$, and from the fluorine content of the commercial blend of tea, Brand A $(6.8 \mathrm{mg}$. $/ \mathrm{ro0} \mathrm{g}$.), described in the preceding paper (Harrison, 1949b), shows that an infusion of $6.75 \mathrm{~g}$./l. would theoretically make $0.42 \mathrm{mg}$. of fluorine available for ingestion. But the difference in daily excretion between the 'with tea' and 'without tea' periods was only $0.25 \mathrm{mg}$., i.e. there was an imbalance of $0.17 \mathrm{mg}$., or $40 \%$. It is reasonably certain that, at least during tea rationing when these studies were made, the most dilute infusion $(6 \cdot 75 \mathrm{~g}$. tea/l.) was generally consumed, and the extraction figures in the preceding paper show that this contains nearly all the fluorine. The imbalance can therefore be only partly due to wastage; for the remainder, several possible explanations are offered. (I) The calculation for fluorine ingested is based on theoretical figures. The actual amount may have been less if blends containing particularly low amounts happened to have been in use at the time. (2) The fluorine in tea may have been partly in a non-available form; or (3) it may have been rendered unavailable through combination with substances that prevent its absorption from the alimentary tract. In all cases in this experiment milk was added to tea, and thus precipitation of calcium fluoride may have taken place. McClure et al. (1945) reported, as a result of balance studies, that $68 \%$ of fluorine present as calcium fluoride in food is absorbed and $95.7 \%$ when present as calcium fluoride solution. (4) The fluorine may have been retained by the skeletal tissues, particularly if their low fluorine content heightens their avidity for this element. It should be pointed out that in New Zealand tea is not considered to be desirable as a beverage for children, and in general it may be stated that children are not given tea at an early age, except that a little may be added to their milk for psychological encouragement. Thus, human skeletal tissues in New Zealand may well have a low fluorine content, a point that has been demonstrated for human teeth, and for animal teeth and bones (Harrison, 1949a).

\section{SUMMARY}

I. Samples of urine collected over $24 \mathrm{hr}$. from fifty-one subjects were analysed for fluorine. The mean daily excretion was $0.49 \mathrm{mg}$. or 0.33 p.p.m. of fluorine. There was a correlation between consumption of tea and excretion of fluorine.

2. In a second experiment, $24-\mathrm{hr}$. collections of urine were made from twenty-eight 
subjects after omission of tea from the diet for 7 days; a further collection was made after 7 days with tea. The mean daily excretion of fluorine without tea was $0.27 \mathrm{mg}$. or 0.18 p.p.m.; with tea the values were $0.52 \mathrm{mg}$. and 0.33 p.p.m. Again, there was correlation between the volume of tea consumed and the daily excretion of fluorine.

3. The combined results of both experiments showed that the mean daily fluorine excretion of seventy-nine subjects whose diet included tea was $0.50 \mathrm{mg}$. The excretion rate was the same for both sexes.

4. It is concluded that tea is a major source of fluorine in New Zealand, where the water supplies contain only a small quantity of this element and the consumption of tea is high.

This study was made with financial support given by the New Zealand Medical Research Council, through the Department of Health, to the Nutrition Research Committee. The author is indebted to Dr Muriel E. Bell for her valuable assistance and advice, to Prof. Margaret M. Murray for her helpful criticism, to Dr C. J. Wilkins, Lecturer in Chemistry at Canterbury University College, for his guidance with the method of fluorine analysis, and to all the subjects who so willingly co-operated in the tests.

\section{REFERENCES}

Bromehead, C. N., Murray, M. M. \& Wilson, D. C. (1943). Lancet, 244, 490.

Chamberlain, G. (1944). N.Z. F. Sci. Tech. 26, sect. B, p. 90.

Chamberlain, G. (1946). N.Z. F. Sci. Tech. 28, sect. B, p. 154 .

Clifford, P. A. (1944). भ. Ass. off. agric. Chem., Wash., 27, 90.

Clifford, P. A. (1945). Ұ. Ass. off. agric. Chem., Wash., 28, 277.

Dahle, D., Bonnar, R. U. \& Wichmann, H. J. (1938). Ұ. Ass. off. agric. Chem., Wash., $21,459$.

Dean, H. T. (1 943). F. Amer. Wat. Whs Ass. 35, I 161 .

Denmead, C. F. (1946). N.Z. F. Sci. Tech. 28, sect. B, p. 158.

Harrison, M. F. (1949a). N.Z. dent. F. 45, 2.

Harrison, M. F. (1949b). Brit. F. Nutrit. 3, 162.

Harvey, W. (1945). Nature, Lond., I55, 175.

Klement, R. (1938). Naturwissenschaften, 26, 145.

Machle, W., Scott, E. W. \& Largent, E. J. (1942). F. Industr. Hyg. Toxicol. 24 , 99.

McClure, F. J. \& Kinser, C. A. (1944). Publ. Hlth Rep., Wash., 59, 1575.

McClure, F. J., Mitchell, H. H., Hamilton, T. S. \& Kinser, C. A. (1945). F. Industr. Hyg. Toxicol. 27, I 59.

Murray, M. M. \& Wilson, D. C. (1948). Brit. dent. F. 84, 97.

Reid, E. (1936). Chin. F. Physiol. ro, 259.

Sub-committee of the Analytical Methods Committee (1944). Analyst, 69, 243.

Van der Merwe, P. K. (1940). Onderstepoort F. vet. Sci. 14, 359.

Whitehorn, J. C. (1921). F. biol. Chem. 45, 449. 